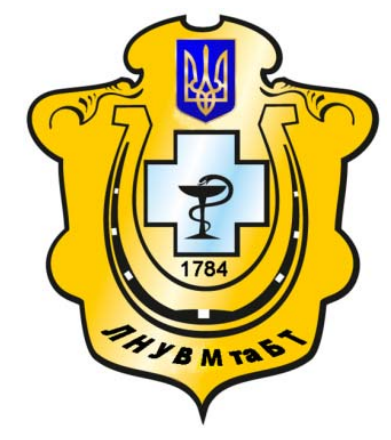

Науковий вісник Львівського національного університету ветеринарної медицини та біотехнологій імені С.З. Гжицького

Scientific Messenger of Lviv National University of Veterinary Medicine and Biotechnologies named after S.Z. Gzhytskyj

doi:10.15421/nvlvet7617

ISSN 2519-2701 print

ISSN 2518-1327 online

$\underline{\text { http://nvlvet.com.ua/ }}$

\title{
Особливості застосування дискримінантного аналізу в сучасних умовах
}

\author{
С.В. Приймак, I.В. Будай \\ rrina.budaj.95@mail.ru \\ Львівський національний університет імені Івана Франка, \\ вул. Коперника, 3, м. Львів, 79000, Україна
}

\begin{abstract}
У статті застосовано методи дискримінантного аналізу для побудови моделей прогнозування банкрутства украйнських підприємств на основі даних фінансової звітності. Досліджено зарубіжні та вітчизняні методи аналізу ймовірності настання банкрутства неплатоспроможного підприємства, визначено їх переваги, недоліки та можливість застосування на украӥнській практиці. У процесі моделювання було окреслено потенційні переваги та вагомі обмеження використання кожного з методів, здійснено аналіз та порівняння значущості та прогнозної якості розроблених моделей, запропоновано шляхи вдосконалення процесів прогнозування банкрутства украӥнських підприємств. На основі найбільш вагомих фінансових коефіцієнтів і балансових моделей оцінки фінансового стану було визначено, які із залучених інтегральних моделей дойільно застосовувати у практичних оцінках кризового стану та діагностиці банкрутства підприємства. Здійснено аналіз ймовірності настання банкрутства для ПАТ «Укртелеком» за зарубіжними моделями, а також за моделлю Терещенка О.О, моделлю Матвійчука А.В. та російською R-модель. Одержані результати дозволяють стверджувати, щьо прогнозування банкрутства із застосуванням обраних методів не є досконалим в українських реаліях через особливості ринку, а тому існує необхідність розробки та використання інших методів, щуо є менш вимогливими до обсягу інформаційної бази.

Ключові слова: підприємство; прогнозування банкрутства; фінансова стійкість; дискримінантний аналіз; аудит; оцінка ймовірності банкрутства за зарубіжснии та вітчизняними методиками; модель Альтмана; модель Спрінгейта; модель Ліса; модель очінки банкрутства Терещенка О.О.; модель очінки банкрутства Матвійчука А.В.; російська R-модель.
\end{abstract}

\section{Особенности применения дискриминантного анализа в современных условиях}

\author{
С.В. Приймак, И.В. Будай \\ rrina.budaj.95@mail.ru
}

Львовский национальный университет имени Ивана Франко, ул. Коперника, 3, г. Львов, 79000, Украина

\begin{abstract}
В статье используются методы дискриминантного анализа для построения моделей прогнозирования банкротства украинских предприятий на основе данных финансовой отчетности. Исследовано зарубежные и отечественные методы анализа вероятности наступления банкротства неплатежеспособного предприятия, определены их преимущества, недостатки и возможность применения на украинской практике. В прочессе моделирования были обозначены потенцильные преимущества и весомые ограничения использования каждого из методов, произведен анализ и сравнение статистической значимости и прогнозной силь разработанных моделей, предложены пути совершенствования процессов прогнозирования банкротства для украинских предприятий. На основе наиболее весомых финансовых коэффициентов и балансовых моделей оиенки финансового состояния было определено, какие из привлеченных интегральных моделей целесообразно применять в практических оченках кризисного состояния и диагностике банкротства предприятия. Осуществлен анализ вероятности наступления банкротства для ОАО «Укртелеком» по зарубежным моделям, а также по модели Терещенко А.О., модели оиенки Матвийчука A.B. и российской R-модель. Полученные результаты позволяют утверждать, что прогнозирование банкротства с использованием выбранных методов не является совершенным в украинских реалиях из-за особенностей
\end{abstract}

Citation:

Pryjmak, S.V., Budaj, I.V. (2017). Features of the application of discriminant analysis in modern conditions. Scientific Messenger LNUVMBT named after S.Z. Gzhytskyj, 19(76), 86-90. 
рынка, а потому существует необходимость разработки и использования иных методов, которые являются менее требовательными к объему информационной базы.

Ключевые слова: предприятие, модель; прогнозирование банкротства; финансовая устойчивость; дискриминантный анализ; аудит; оценка вероятности банкротства по зарубежным и отечественным методикам; модель Альтмана; модель Спрингейта; модель Лиса; модель оченки банкротства Терещенка А.А, модель оченки банкротства Матвийчука А.В., руская $R$-модель.

\title{
Features of the application of discriminant analysis in modern conditions
}

\author{
S.V. Pryjmak, I.V. Budaj \\ rrina.budaj.95@mail.ru \\ Ivan Franko National University of Lviv, \\ Kopernyka Str., 3, Lviv, 79000, Ukraine
}

In the article there have been applied the methods of discriminant analysis to build bankruptcy prediction models for Ukrainian business companies based on financial reporting data. Investigated foreign and domestic methods of analysis of the probability of insolvent companies' bankruptcy, defined their advantages and disadvantages and the possibility of using for Ukrainian practice. During the modelling the potential advantages and the significant restraints of using both methods, the analysis and comparison of statistical significance and forecasting power of the developed models are conducted. It has been determined, what models should be applied in crisis condition practical assessment and the bankruptcy diagnostics of the enterprise. The analysis of the likelihood of bankruptcy for JSC «Ukrtelecom» on foreign models and by O.O Tereshchenko model, model evaluation Matviychuk A. and the Russian R-model. The obtained results allow to assert that prediction of bankruptcy of companies using the chosen methods is not perfect in Ukrainian reality due to the peculiarities of the market; therefore, there is a need for developing and applying alternative methods which are, primarily, less demanding of information base volume.

Key words: enterprise; bankruptcy forecasting; financial stability; discriminant analysis; audit; assessment of the probability of bankruptcy by foreign and domestic practices; Altman model; Sprinheyt model; Model Lisa; bankruptcy evaluation model Tereshchenko O.O; model for evaluating bankruptcy Matviychuk A.; russian R-model.

\section{Вступ}

В сучасних умовах економічного та політичного стану в Україні простежується стійка тенденція до збільшення кількості фінансово-неспроможних підприємств, що призводить до банкрутства. Наслідки цього явища на підприємства негативно впливає на всіх суб'єктів, з якими воно співпрацює, а саме: постачальників, фінансово-кредитних установ, інвесторів, працівників, а також на загальне економічне становище економіки країни. Одним 3 найважливіших інструментів системи раннього запобігання та методом прогнозування банкрутства підприємств $є$ дискримінантний аналіз.

У зарубіжній практиці питаннями розробки методів і моделей прогнозування банкрутства на основі дискримінантного аналізу займалися такі вчені: Спрінгейт, Альтман, Бівер, Таффлер та Тішоу, Ліс та багато інших. На питання доречності та ефективності використання дискримінаційних моделей у вітчизняній практиці звертали увагу такі економісти: О. Терещенко, А. Матвійчук, О. Базілінська, В. Подольська, О. Шапурова (Beaver, 1966; Tereschchenko, 2000; Bilyk, 2005; Matvijchuk, 2007; Klochan et al., 2010; Kostinina and Majboroda, 2012).

Метою роботи є здійснення аналітичного огляду сучасних методів та моделей дискримінантного аналізу, які використовуються для проведення діагностики фінансового стану підприємств; проведення порівняльного аналізу їх параметрів та визначення найоптимальніших моделей для українських підприємств.

\section{Матеріал і методи досліджень}

Для дослідження процесу діагностики ймовірності банкрутства та дискримінантного аналізу використані інформаційні матеріали провідних науковцівекономістів, а саме монографії і публікації. Серед методів прогнозування банкрутства використано модель «Z-рахунку» Е. Альтмана, модель Спрінгейта, модель Ліса, модель Терещенка О.О., модель Матвійчука A.B та російська R-модель, а також загальнонаукові методи дослідження. Одним із найголовніших матеріалів слугувала фінансова звітність підприємства «Укртелеком» за 2015 рік. Методами дослідження $\epsilon$ порівняльний аналіз, системний підхід до формування системи запобігання банкрутству, статистичні та аналітичні методи збору й оцінювання інформації.

\section{Результати та їх обговорення}

Під дискримінантним аналізом здебільшого розуміють комплекс методів та прийомів математичної статистики, з допомогою яких здійснюється класифікація аналізованих елементів залежно від значень обраної сукупності показників відповідно до побудованої шкали інтерпретації. Головними передумовами для проведення дискримінантного аналізу є наявність двох або більше груп та можливість виміру кількох змінних для визначення схожості чи несхожості цих груп. У процесі аналізу підбирається певна система показників, дослідивши значення яких можна віднести підприємство до того чи іншого класу та з високим рівнем ймовірності спрогнозувати його майбутній фінансовий стан. 
Здійснення комплексної оцінки застосування дискримінантного аналізу на основі прогнозування фінансового стану підприємства доцільно здійснювати на конкретному прикладі. В даному випадку це буде Публічне акціонерне товариство «Укртелеком». Отже, розглянемо зарубіжні та вітчизняні моделі передбачення банкрутства.

Українські підприємства можуть застосовувати тест, який запропоновано Е. Альтманом у 1983 році для підприємства, акції яких не котируються на біржі:

$\mathrm{Z}=0,717 \times \mathrm{X}_{1}+0,847 \times \mathrm{X}_{2}+3,107 \times \mathrm{X}_{3}+$ $0,42 \times X_{4}+0,995 \times X_{5}$,

де $\mathrm{X}_{1}$ - власний оборотний капітал / загальна вартість активів;

$\mathrm{X}_{2}$ - нерозподілений прибуток / загальна вартість активів;

$\mathrm{X}_{3}$ - прибуток до виплати процентів / загальна вартість активів;

$\mathrm{X}_{4}$ - балансова вартість власного капіталу / позиковий капітал;

$\mathrm{X}_{5}$ - чиста виручка / загальна вартість активів.

$\mathrm{Z}<1,23$ - дуже висока ймовірність банкрутства у найближчі 2-3 роки;

$Z>1,23$ - ймовірність банкрутства дуже низька.

Для підприємства «Укртелеком» отримано такі дані:

$Z=-0,192-0,396+0,016+0,953+0,535=0,916$ отже $Z>1,23$, що означає низьку ймовірність банкрутства.

Модель Спрінгейта має вигляд:

$\mathrm{Z}=1,03 \times \mathrm{A}+3,07 \times \mathrm{B}+0,66 \times \mathrm{C}+0,4 \times \mathrm{D}$,

де $\mathrm{A}$ - робочий капітал / загальна вартість активів;

В - прибуток до сплати відсотків та процентів / загальна вартість активів;

$\mathrm{C}$ - прибуток до сплати податків / короткострокові зобов'язання;

D - обсяг продажу / загальна вартість активів.

Вірогідність банкрутства підприємства моделі оцінюється такими значенням Z:

- менше ніж 0 - напівбанкрут;

- від 0 до 1 - загрожує банкрутство, якщо не здійснити санацію;

- від 1 до 2 - фінансова стійкість порушилась, але за умови переходу на антикризове управління банкрутство не загрожує;

- понад 2 - вважається фінансово стійким, банкрутство не загрожує.

Розрахувавши всі необхідні складові на основі фінансової звітності підприємства «Укртелеком», маємо такі дані:

$Z=-0,057+0,196+0,018+0,215=0,372$, це свідчить про те, що підприємству загрожує банкрутство, якщо не здійснити санацію.

Модель Ліса для оцінки фінансового стану оцінює схильність підприємства до банкрутства на основі показників ділової активності та рентабельності. Модель Ліса має вигляд:

$$
\mathrm{Z}=0,063 \times \mathrm{A}+0,092 \times \mathrm{B}+0,057 \times \mathrm{C}+0,001 \times \mathrm{D},
$$

де, A - оборотні активи / загальна вартість активів;

В - операційний прибуток / загальна вартість активів;
$\mathrm{C}$ - нерозподілений прибуток / загальна вартість активів;

$\mathrm{D}$ - власний капітал / позиковий капітал.

$\mathrm{Z}$ нижче за 0,037 - висока загроза банкрутства.

Для підприємства «Укртелеком» отримано такі дані:

$\mathrm{Z}=0,009+0,006-0,027+0,002=-0,01$

Даний показник $\epsilon$ нижчим за 0,037 , що означає високу загрозу банкрутства.

У вищеподаних моделях під час визначення банкрутства орієнтація на фактори ділової активності та рентабельності не завжди виправдана, оскільки збиткове підприємство не означає банкрутство. Також варто зазначити, що дані моделі складалися на основі фінансового стану зарубіжних підприємств і тому не $\epsilon$ адаптованими до фінансової ситуації на українських підприємствах. Для наших підприємств більше підходять такі моделі як Терещенка О.О., Матвійчука А.В та російська R-модель (R-модель прогнозу ризику банкрутства).

Досить поширеною в Україні $\epsilon$ діагностика банкрутства підприємства за моделлю Терещенка О.О. Ця модель О.О. Терещенка визначається за формулою:

$\mathrm{Z}=1,5 \mathrm{X} 1+0,08 \mathrm{X} 2+10 \mathrm{X} 3+5 \mathrm{X} 4+0,3 \mathrm{X} 5+0,1 \mathrm{X} 6$,

де X1 - відношення грошових надходжень до зобов'язань;

X2 - відношення валюти балансу до зобов'язань;

X3 - відношення чистого прибутку до середньорічної суми активів;

X4 - відношення прибутку до виручки;

X5 - відношення виробничих запасів до виручки;

X6 - відношення виручки до основного капіталу.

Коли $\mathrm{Z}>2$ - банкрутство не загрожує, $1<\mathrm{Z}<2$ фінансова стійкість порушена, $0<Z<1-$ існує загроза банкрутства.

Для підприємства «Укртелеком» маємо такі дані: $Z=0,06+0,26+0,2+0,3+0,006+0,71=1,536$

Отже, $1<\mathrm{Z}<2$, що означає порушення фінансової стійкості.

Методика розрахунку моделі ще одного українського економіста Матвійчука А.В. подана у формулі:

$\mathrm{Z}=0,033 \mathrm{X}+0,268 \mathrm{X} 2+0,045 \mathrm{X} 3-0,018 \mathrm{X} 4-$ $0,004 \times 5-0,015 \times 6+0,702 \times 7$,

де X1 - коефіцієнт мобільності активів;

X2 - коефіцієнт оборотності кредиторської заборгованості;

Х3 - коефіцієнт оборотності власного капіталу;

X4 - коефіцієнт окупності активів;

X5 - коефіцієнт забезпеченості власними оборотними засобами;

Х6 - коефіцієнт концентрації залученого капіталу;

X7 - коефіцієнт покриття боргів власним капіталом.

Якщо при застосуванні даної моделі для оцінки фінансового стану ми отримуємо значення $Z$, яке більше від 1,104 , то це свідчить про задовільний фінансовий стан підприємства та низьку ймовірність його банкрутства. I чим вище значення $Z$, тим стійкішим є становище компанії. Якщо ж значення $Z$ для підприємства виявилося меншим від 1,104, то 
виникає загроза фінансової кризи. 3 подальшим зменшенням показника Z імовірність банкрутства аналізованого підприємства збільшується.

Для підприємства «Укртелеком» отримано такі дані:

$Z=0,006+0,813+0,024-0,053+0,002-0,005+$ $1,596=2,383$

Даний показник свідчить про задовільний стан підприємства, оскільки $Z>1,104$.

Російські вчені Іркутської економічної академії пропонують для прогнозування ризику банкрутства $\mathrm{R}$-модель, яка має наступний вигляд:

$\mathrm{R}=0,38 \mathrm{~K} 1+\mathrm{K} 2+0,054 \mathrm{~K} 3+0,63 \mathrm{~K} 4$,

де К1 - відношення оборотного капіталу до середньорічної суми активів;

К2 - відношення чистого прибутку до середньорічної суми власного капіталу;
К3 - відношення виручки до середньорічної суми активів;

К4 - відношення чистого прибутку до сукупних затрат.

Якщо $\mathrm{R}=0$ - імовірність банкрутства максимальна $(90-100 \%), 0-0,18$ - висока $(60-80 \%), 0,18-0,32-$ середня (35-50\%), 0,32-0,42 - низька (15-20\%), більше ніж 0,42 - мінімальна (до 10\%).

Для підприємства «Укртелеком» отримано наступні дані:

$\mathrm{R}=0,385+0,031+0,036+0,34=0,792$, отже $\mathrm{R}<0,42$, що означає мінімальну ймовірність банкрутства, а саме до $10 \%$.

Отже, у таблиці 1 наведемо розрахунок розглянутих вище моделей діагностики кризового стану для ПАТ «Укртелеком» за 2015 рік. Нагадуємо, що для цього ми використали річну фінансову звітність підприємства.

Таблиия 1

Діагностика кризового стану підприємства за моделями діагностики банкрутства

\begin{tabular}{|l|c|l|}
\hline \multicolumn{1}{|c|}{ Модель } & Показник & \multicolumn{1}{|c|}{ Результат } \\
\hline Z-показник за моделлю Альтмана 1983 року & 0,916 & Низька ймовірність банкрутства \\
\hline Z-показник за моделлю Спрінгейта & 0,372 & Достатньо висока ймовірність банкрутства \\
\hline Z-показник за моделлю Ліса & $-0,01$ & Висока загроза банкрутства \\
\hline Z-показник за моделлю Терещенка О.О. & 1,536 & Фінансова стійкість порушена \\
\hline Z-показник за моделлю Матвійчука А.В. & 2,383 & Задовільний фінансовий стан \\
\hline R-модель Іркутської економічної академії & 0,792 & Імовірність банкрутства мінімальна \\
\hline
\end{tabular}

Здійснивши аналіз ймовірності настання банкрутства для підприємства ПАТ «Укртелеком» за 2015 рік, було виявлено неоднозначну ситуацію. Так, моделі Матвійчука A.В., російська R-модель та модель Альтмана показали стабільну ситуацію, тимчасом як згідно моделі Спрінгейта та Ліса загроза банкрутства $\epsilon$ досить високою. За моделлю, яку розробили українські науковці, а саме Терещенко О.О., висновки, щодо фінансового стану ПАТ «Укртелеком» можна зробити такі: підприємство має фінансовий стан який не можливо віднести до стабільного або нестабільного, і тому рекомендовано провести додатковий аналіз. Спираючись на те що, Терещенко при розробці своєї моделі використовував показники діяльності українських підприємств та враховував всі реалії вітчизняної моделі господарювання, саме його формула має давати найбільш точні результати щодо фінансового стану підприємства. Щодо висновків, які були зроблені після проведення аналізу за допомогою моделі Іркутських вчених, то вони показують, що підприємство має мінімальну загрозу банкрутства. Спираючись на те, що система господарювання в економіках Росії та України дуже схожі, то отримані результати щодо фінансового стану мають бути наближені до реального стану справ.

Отже, роблячи загальний висновок, можна сказати що загалом підприємство перебуває у доброму фінансовому становищі, але 3 огляду на недосконалість моделей та однобокість такого аналізу, було б доцільніше проаналізувати додатково показники ліквідності, рентабельності, фінансової стійкості та ділової активності, що дало б змогу більш розгорнуто побачити картину фінансового стану та 3 високою долею ймовірностю зробити правильні висновки.
27 квітня 2016 року аудиторською фірмою «ПрайсвотерхаусКуперс(Аудит)» було проведено незалежний аудит фінансової звітності ПАТ «Укртелеком» станом на 31 грудня 2015 року. За результатами аудиту була висловлена умовно-позитивна думка, оскільки фінансова звітність відображає достовірно, в усіх суттєвих аспектах, фінансовий стан компанії на 31 грудня 2015 року, іiі фінансові результати та рух коштів за рік, що закінчився на зазначену дату, відповідно до Міжнародних стандартів фінансової звітносTi.

Засторогою є можливість зазнавати у найближчому майбутньому впливу політичної та економічної невизначеності, що спостерігається в Україні. Ця невизначеність впливає на оцінку справедливої вартості основних засобів і сум відшкодування товарноматеріальних запасів, торгової та іншої дебіторської заборгованості. Крім того, така невизначеність може вплинути на спроможність домовитись про перегляд умов iï поточних позикових коштів. Станом на кінець року поточні зобов'язання перевищують поточні активи на 650769 тисяч гривень без урахування можливого додаткового ефекту знецінення дебіторської заборгованості за кредитом від материнської компанії в сумі 734006 тисяч гривень та дебіторської заборгованості за процентами, нарахованими за облігаціями, в сумі 26870 тисяч гривень. Цей факт свідчить про наявність істотної невизначеності, що призводить до порушення фінансової стійкості. Саме ця невизначеність може викликати значні сумніви у спроможності підприємства продовжувати свою діяльність як безперервно функціонуюче підприємство. 


\section{Висновки}

Отож, співставивши наші дослідження на основі дискримінантного аналізу та офіційний аудиторський висновок, можна зазначити, що найбільш оптимальною моделлю прогнозування банкрутства $\epsilon$ модель Терещенка О.О. Саме результати даної моделі відповідають заключенню аудиторського висновку. Ця оптимальність зумовлена тим, що модель О.О.Терещенка має значні переваги над традиційними методиками:

- модель є зручною в застосуванні;

- розроблена на використанні вітчизняних статистичних даних;

- враховується сучасна міжнародна практика;

- за рахунок використання різноманітних модифікацій базової моделі до підприємств різних видів діяльності вирішує проблему критичних значень показників;

- враховує галузеві особливості підприємства.

Підбиваючи підсумок, необхідно зазначити, що моделі багатофакторного аналізу ймовірності банкрутства, розроблені іноземними фахівцями, є досить ефективними і часто використовуються за кордоном. Але в Україні вони застосовуються дуже рідко, що пов'язано з такими труднощами:

1) відсутністю достатніх коштів для закупівлі та адаптації західних методик до вітчизняних умов господарювання;

2) недостатнім рівнем об'єктивності показників, які відображаються підприємствами у фінансовій звітності (проблематика подвійної бухгалтерії).

3) часова невідповідність, яка передбачає застосування моделі в тому часі, в якому вона розроблена;

4) невідповідність методики визначення параметрів моделі, яка потребує точного дотримання методичних прийомів оцінки показників, що були розроблені автором моделі. Основним недоліком використання вищеподаних методів $\epsilon$ те, що всі вони як інформаційну базу використовують зовнішню звітність підприємства.
Перспективи подальших досліджень. Отже, в умовах все більшого зростання чисельності банкрутства українських підприємств необхідно обрати таку модель для діагностики фінансового стану та ймовірності настання банкрутства суб'єктів господарювання, яка б враховувала всі особливості саме українського економічного простору та галузі, в якій функціонує підприємство. Як результат, в сучасних умовах розвитку вітчизняної економіки виникає необхідність більш системного підходу до аналізу фінансового стану підприємства через створення власних економетричних моделей діагностики кризового стану, які б враховували результати виробничої, комерційної і фінансової діяльності підприємств.

\section{Бібліографічні посилання}

Bilyk, M.D. (2005). Sutnist i ocinka finansovoho stanu pidpryjemstv. Finansy Ukrajiny. 3, C.117-128 (in Ukrainian).

Klochan, V.P., Klochan, V.V., Kostanevych, N.I., Kostyrko, A.H. (2010). Ocinka modelej diahnostyky bankrutstva. Miznarodnyj naukovo-vyrobnychyj zurnal «Economica APK» 1, 97-101 (in Ukrainian).

Kostinina, O.M., Majboroda, O.E. (2012). Metody ta modeli diahnostyky kryzovoho stanu pidpryjemstva . Visnyk SumDu. Serija «Economica». 4, 91-97 (in Ukrainian).

Matvijchuk, A.V. (2007). Diahnostyka bankrutstva pidpryjemstva. Upravlinna economicoju: terytorija ta praktyka. Zbirnyk naukovych prac, 20-28 (in Ukrainian).

Tereschchenko, O.O. (2000). Finansova sanacija ta bankrutstvo pidpryjemstva. K.: KNEU (in Ukrainian).

Beaver, W. (1966). Financial Ratios as Predictors of Failure. Journal of Accounting Research. 4, 71-111.

Altman, E.I. (1968). Financial Rations, Discriminent Analysis and the Prediction of Corporate Bankruptcy. Journal of Finance. 23(4), 589-609.

Стаття надійшла до редакиї 2.03.2017 